\title{
Juridical Review Of Default In A Motorcylcle Leasing Agreement (Research Study At. PT Adira Dinamika Multifinance, Tbk)
}

\section{Yosphi Kaena}

Sumatera University Faculty Of Law. E-mail: yosphikaena@gmail.com

\begin{tabular}{l} 
ARTICLE INFO \\
\hline Keywords: \\
Motorcycle Leasing \\
Agreement \\
\\
Article history: \\
Received Oct 30, 2021; \\
Revised Nov 28, 2021; \\
Accepted Des 25, 2021; \\
Online Jan 30, 2022. \\
\end{tabular}

\begin{abstract}
Development in a society is seen in the development of existing institutions in that society, both in the economic, social, cultural and political fields. In line with the increasing number of National Development activities, the participation of the private sector in the implementation of development will also be increased. This situation, either directly or indirectly, will demand more active activities in the financing sector. Various efforts to raise public funds have been made through the establishment of government policies. Business expansion requires financing of funds, apart from the banking system and non-bank financial institutions that are known, there are other alternative financing systems, namely: "leasing. Basically the agreement that has been made applies as a law for the parties as stated in article 1338 of the Civil Code. However, in reality, it is not uncommon for the parties to carry out the agreement that has been made, which is known as "default". Such is the case in the leasing agreement. The occurrence of congestion in the payment system, violations of the provisions in the leasing contract such as sub-leasing, pledging goods that are the object of the lease or selling the goods with the aim of breaking away from rental payments are examples of forms of default committed by the lessee. This is what ultimately causes execution by the lessor of the leasing object.
\end{abstract}

This is an open access article under the CC BY-NC license.

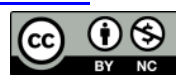

\section{Introduction}

"Leasing as a financial institution is one form of business in the field of non-bank financial institutions that have a very important role in financing. The activities of these financial institutions are carried out in the form of providing funds or capital goods by not withdrawing funds directly from the public in the form of demand deposits, deposits, savings, and promissory notes. "Although leasing is still young, since 1974 with the approval of the Minister of Finance," However, recently leasing activities have grown tremendously because of its function at the same level as a bank as a medium-term financing source from (1) one year to (5) five years.

Although still new, as an alternative to financing techniques, leasing business in recent years has played an increasingly important role for the Indonesian economy. The factors that cause leasing to grow so fast are because leasing is a system that is in accordance with the current direction of the economy, which is very profitable from a management point of view. In terms of the national economy, leasing has introduced a new method to acquire capital equipment and increase working capital. 
"Compared to financing through loans from banks, leasing is more flexible and provides convenience compared to financing loans through banks. This is especially true for newly established businesses, which do not yet have assets that can be used as collateral. The difficulty of the public in accessing funds from banks is due to, among other things, the uneven distribution of bank credit, the obligation of banks to apply the principle of "prudential banking", the obligation of debtors to submit guarantees, and the limited ability of banks' own capital."6, while in leasing, the entrepreneur does not need to provide collateral because the assets obtained by the lessee are at the same time a guarantee for the leasing company. With the financial assistance from this financial institution, it is hoped that the community (business actors) can overcome one of the most common crucial factors they experience, namely the capital factor."

Until now there is no law governing leasing in Indonesia. The provisions governing this matter are still in the form of a Decree of the Minister of Finance and other regulations, namely the Joint Decree of the Three Ministers, namely the Minister of Finance, the Minister of Industry, and the Minister of Trade of the Republic of Indonesia No. Kep- 122/MK/IV/2/1974, No. 32/MK/SK/2/1974, No. 30 Kpb/I/1974 February 7, 1974.

With the principle of freedom of contract, it is also what has given birth to leasing agreements that are known in the community. Leasing institutions are not known in the Civil Code, but are known in practice in the community. However, in reality, people still question what form the leasing agreement takes, whether it is a lease agreement, lease purchase or sale and purchase in installments. The limited availability of literature in the field of leasing or writings in other forms is a factor causing the lack of public understanding of leasing itself.

Basically the agreement that has been made applies as a law for the parties as stated in article 1338 of the Civil Code. However, in reality, it is not uncommon for the parties to carry out the agreement that has been made, which is known as "default". Such is the case in the leasing agreement. The occurrence of congestion in the payment system, violations of the provisions in the leasing contract such as sub-leasing, pledging the goods that are the object of the lease or selling the goods with the aim of escaping from rental payments are examples of forms of default committed

\section{Method}

The research method used in the preparation of this thesis is a normative juridical method with a qualitative approach. The qualitative approach method is useful for conducting comprehensive data analysis and is an integral unit (holistic).

In research with the normative method, data collection with this method is done by taking supporting sources for writing this thesis with primary legal materials in the form of positive legal sources regarding leasing agreements that are still valid. Then it is supported by secondary and tertiary legal materials in the form of information obtained from theses, legal dictionaries, various literatures in libraries, and so on.

"Furthermore, to obtain supporting data in writing this thesis, it is done by conducting field observations (research studies), and also in-depth interviews (in depth interviewing)"8 with the resource persons relating to the title of this thesis by using general interview instructions that have been prepared in advance on several informants who know the main issues that are the object of research.

\section{Analysis And Results}




\subsection{Legal Measures By Lessor In The Event Event Default Against Lesse}

a. Definition and Forms of Default.

"The term "default" comes from the Dutch language, which means "poor performance". Default is a term that refers to the non-performance of achievements by the debtor. Default There are 4 (four) types of debtors (negligence), namely:

1) Didn't do what it was supposed to do.

2) It does what it promises, but not as promised.

3) Did what it promised, but it was too late

4) Doing something that according to the agreement is not allowed to do.

A negligent debtor, who is in default, can be sued before a judge and the judge will pass a judgment that is detrimental to the defendant. This negligence or default on the part of the debtor must be officially stated first, namely by warning the debtor that the debtor requires immediate payment or in a short period of time, which is referred to as a "summation". According to the law the warning must be in writing with a warrant or with a similar deed (Article 1238 of the Civil Code).

"What is meant by a warrant in Article 1238 of the Civil Code is an official warning by a court bailiff. Meanwhile, what is meant by a similar deed is an ordinary (not official) writing, a letter or a telegram with the same purpose, namely to warn the debtor to fulfill his achievements in an instant or within a certain time (Arrest Hoge Raad). So, the breach of promise / default / default by the debtor (lesse) who owes the debt must be stated formally with a warning (summation)."

Thus the default by the debtor basically has to be done formally, namely by commemorating the debtor (lesse). The obligation in Article 1238 of the Civil Code to provide a statement of negligence or warning can be eliminated by entering into a provision in the agreement (contract) in the form of a clause stating that the lessee's default is sufficient to prove that the payment period has passed. installments of rent, or from the time of taking actions prohibited in the agreement without having to require a statement or written warning from the lessor. ${ }^{63}$

The forms of default from the lesse are as follows:

1) Lesse does not pay the rental on a predetermined date or pays only a few days after a certain date, or he makes payments but not as agreed.

2) Lesse does not pay a penalty for being late in paying the rental or being late in paying the fine.

3) Lesse take actions that are prohibited from being carried out in the leasing agreement, such as conducting sub-lease, pledging goods or removing goods labels and so on.

If the debtor is in default, the creditor can choose between several possible claims as referred to in Article 1267 of the Civil Code, namely:

1) Request the implementation of the agreement, even though the implementation of this agreement is too late.

2) Asking for compensation only, namely the loss suffered, because the agreement was not or was late to be implemented, or implemented but not as it should be.

3) Demanding the implementation of the agreement accompanied by compensation for the losses suffered by him as a result of the delay in the implementation of the agreement.

As a result of a default by the lesse, the lessor has the right to take back the leasing object that is in the lesse's control. In the event of default (default) by the lesse, the lesse grants an irrevocable approval/permission to the lessor to enter the yard or place where the leased goods are located and take the goods which are the object of the leased. with or without police 
assistance. The taking back of the leasing object is called the unilateral termination or cancellation of the leasing agreement by the lessor.

In the lease agreement (leasing) signed between PT. Adira Finance and the lessee have a clause in the agreement stating that the cancellation of the leasing agreement does not need to be canceled to the judge as stipulated in Article 1266 of the Civil Code, because in the agreement signed by the parties, it has been agreed to release the provisions. in Article 1266 of the Civil Code.

\section{b. Lessor's Legal Remedies in the Event of Default.}

Debtors who have defaulted will be sued before the court. The negligence or default of the debtor will result in the debtor being given a warning letter (sumasi) from the creditor. At PT. Adira, if the lesse/debtor is in default by paying arrears, then PT. Adira will issue a warning letter (summation) / SP I and II to the lesse / debtor. The first warning letter contains a warning to the lesse / debtor to immediately settle his obligations to the lessor / creditor with the grace period given in this SP is 14 (fourteen) calendar days, where for each delay a fine of $0.2 \%$ per day.

If the period of 14 days has passed, the lesse / debtor does not pay off his obligations, then he gives a second warning letter to the lesse. If within 14 (fourteen) days the lesse does not fulfill its obligations as warned in the subpoena, then PT. Adira Finance will execute the leasing collateral from the lessee. The executed collateral will be handed over by the executor to PT. Adira Finance by making the Minutes of Handover of Motor Vehicles.

PT. Adira Finance still provides an opportunity for the lesse / debtor to redeem the collateral that has been executed on the condition that the lesse / debtor must pay off the payment that has been due plus a fine for the delay within 7 days from the date of the Handover of the Motor Vehicle it at PT. Adira Finance. If within the 7 (seven) day grace period that has been given after the Minutes of Handover of the Motorized Vehicle, the lesse / debtor does not also pay off the arrears of rent, then PT. Adira Finance has the right to sell in public or privately or with the role of another party the guarantee at a fair market price and with terms and conditions deemed good by PT.

"As is well known, the leasing agreement cannot be decided unilaterally, but with the event of a breach of promise imposed on the lesse, the lessor has the right to terminate the leasing agreement in question by taking back the leasing object that is used as collateral. In Article 1266 of the Civil Code it is determined that although the conditions for cancellation have been included in a reciprocal agreement, and one of the parties does not fulfill its obligations, the unilateral termination of a reciprocal agreement must be carried out by a judge's decision. However, because the provisions of Article 1266 of the Civil Code are only regulating, they can be overridden by the parties. Therefore, in a leasing agreement, it is better to include a clause that overrides the application of Article 1266 of the Civil Code.

\section{c. Execution of Debt Guarantees as a Result of Default by the Lesse.}

"The execution of fiduciary guarantees is regulated in Article 29 to Article 34 of Law no. 42 of 1999 concerning fiduciary guarantees. What is meant by the execution of a fiduciary guarantee is the confiscation and sale of objects that are the object of a fiduciary guarantee. The cause of the execution of fiduciary guarantees is because the debtor / fiduciary giver (lesse) breaks his promise or does not fulfill his performance on time, to the fiduciary recipient (lessor), even though they have been given a subpoena."

As has been explained, one form of default on the part of the lessee is to make arrears in rent payments for the leased goods. If the lessee has been given a warning letter (SP) I and II but the 
lesse does not also pay the rent in arrears plus a fine for late payment of $0.2 \%$ per day for each delay, PT. Adira Finance will execute the debt collateral which is bound by the fiduciary.

Based on the provisions in Article 29 paragraph (1) of Law no. 42 of 1999 concerning Fiduciary Guarantees (UUJF), it can be seen that if the debtor or fiduciary giver is in breach of contract, the execution of the object that is the object of the fiduciary guarantee can be carried out in the following ways:

1) Execution based on Grosse Fiduciary Guarantee Certificate or Executional Title (by fiat execution) contained in the Fiduciary Guarantee Certificate, which is carried out by the fiduciary recipient.

2) Execution based on execution parate execution through public auction by fiduciary recipient.

3) Execution by selling under the hands by creditors, in this way the highest price can be obtained that benefits the parties. This sale is carried out after 1 month has passed since the fiduciary giver and recipient have notified in writing to interested parties and announced it in at least 2 newspapers circulating in the area concerned (Article 29 of the UUJF).

In order to be able to carry out the execution of the object of fiduciary security, the fiduciary giver is obliged to submit the object that is the object of the fiduciary guarantee as stated in Article 30 of Law no. 42 of 1999 "The fiduciary giver is obligated to hand over the object that is the object of the fiduciary guarantee in the context of the execution of the fiduciary guarantee".

Thus, the sale of the fiduciary guarantee that has been executed shows that the lessor cannot become the owner of the fiduciary guarantee that has been executed, the lessor is only entitled to sell the object of the fiduciary guarantee either on the basis of an executive title, auction or underhand sales (Article 30 UUJF).

From the sale of the fiduciary guarantee, if there is a remaining sale price after paying the principal, interest and other costs, it is returned to the lesse / fiduciary guarantor. On the other hand, if the proceeds from the sale of the collateral are insufficient to pay off the debt, the lessee remains bound or responsible for paying the debt to the lessor/fiduciary guarantee recipient.

At PT. Adira Finance, provided that PT. Adira as the creditor will return the remaining sale price of the fiduciary collateral as stated in the clause in the lease agreement made by PT. Adira Finance. Based on the results of an interview with Mr. Ramadhan Valentino, as Deputy Branch Head of PT. Adira Finance said that the obstacles that are often faced when carrying out executions are where the lessee and the object of execution are no longer found, the leased goods are in the hands of a third party or the leased goods have been transferred to a third party by reselling them, and the lesse's uncooperative attitude, it is not uncommon for the lesse to fight against the executor at the time of execution.

\section{d. Dispute Settlement Process in the Leasing Agreement.}

Basically there are 2 forms of dispute resolution, namely:

1) Settlement outside the Court.

"Out-of-court settlements are referred to as "Alternative Dispute Resolutions". ${ }^{71}$ Alternative dispute resolution institutions, including arbitration, have been regulated in a separate statutory regulation, namely Law no. 30 of 1999 concerning Arbitration and Alternative Dispute Resolution."

The procedures for resolving disputes outside the court are:

a) Negotiation. 
In negotiations there is no third party. Negotiation is a 2 (two) way communication designed to reach an agreement when both parties have the same or different interests. In the formulation of Article 6 paragraph (2) of Law no. 30 of 1999, states "Basically the parties can and have the right to resolve disputes that arise between them." Agreement on the settlement must be in a written form agreed to by the parties

b) Mediation.

The definition of mediation according to Mas Ahmad Santosa and Anton L. P Hutapea is "Negotiations attended by a neutral third party who do not have the authority to decide." "In dispute resolution through mediation there is the involvement of a third party which is desired by the parties as a mediator because of their expertise in the disputed field. A third party, also called a mediator, serves to provide facilities for the parties in negotiations to reach an agreement."

\section{2) Settlement Through Court.}

If the lessor's efforts to take back his property controlled by the lessee cannot be carried out peacefully, then in this case the lessor can resolve this issue through the Court. In order to repair or restore the rights of the lessor who has suffered losses due to the lesser's breach of promise as agreed in the leasing agreement and also as a result of the lesse's unlawful actions, the lesse may, among other things, sue the court for the following matters:

The litigation process through the courts is not beneficial for the lessor, because the slow legal process will bring losses to the lessor where the goods being leased will be sealed or confiscated which of course will no longer produce and the quality will decrease.

At PT. Adira, settlement through legal channels is very rarely done. This is because settlement through the courts takes a lot of time and costs. In addition, the value of the goods decreases (wears out) at the time the dispute inspection is carried out. However, even so, PT. Adira Finance does not rule out the possibility of resolving disputes through legal channels (courts), in this case the appointed court is the District Court where the agreement was made.

\section{Conclusion}

Each agreement applies as law for the parties who make it, thus the parties involved in the agreement are subject to the applicable provisions contained in the agreement. The provisions in the leasing agreement cover the rights and obligations of each party and the things that are prohibited from being done in the leasing agreement. If one of the parties does not carry out its obligations as specified in the leasing agreement, it will give the other party the right to prosecute in connection with the non-performance of the obligation, namely to request the fulfillment of the obligation (the agreement), to ask for compensation due to the nonperformance of the agreement.

In the leasing agreement (lease) made by PT. Adira Finance, PT. Adira Finance, as the lessor, has the right, among others, to receive payment of rent for the leased goods from the lessee, to sell or transfer the rights and to pledge the equipment with terms and conditions determined by the lessor (PT. Adira Finance), has the right to enter the land and the building where the equipment is placed and inspect and investigate the condition of its repair or how to use the equipment, in the event of negligence by the lessee in paying the rent, PT. Adira Finance (lessor) has the right to take legal remedies such as asking the lesse to immediately stop using the equipment and hand over control of the equipment to PT. Adira (lessor), while the obligations of PT. 
The rights of the lessee include, among others, the use of the leased goods in accordance with the provisions of the agreement. And at the end of the lease contract, the lesse has the option to determine whether the lesse will extend the lease term, or to extend the lease term or to purchase the leased goods in accordance with the mutually agreed residual value. Meanwhile, the obligations of the lessee are, among others, to periodically pay the rental fee for the leased goods to the lessor (PT. Adira Finance), to pay taxes on the leased goods, and to maintain and manage the collateral as well as possible.

In the leasing agreement, the assets obtained by the lessee are at the same time a guarantee for the leasing company which is bound on a fiduciary basis. The collateral goods are still in the hands of the lesse (debtor), thus the lesse is the economic owner, and the lessor is the legal owner or nominal owner. Even though in the leasing agreement the collateral has been fiduciary, but if there are things that are considered to raise doubts about the integrity of the prospective lesse, the lessor (leasing company) will ask for other guarantees from the lesse whose purpose is to gain a sense of security for the lessor. because leasing is a transaction that involves a large amount of capital and to anticipate the possibility of default by the lessee. The collateral requested can be in the form of personal guarantees or material guarantees. Material guarantees such as mortgages and pawns. Meanwhile, individual guarantees can be in the form of personal guarantees (personal guarantees), guarantee agreements (borgtocht), guarantee agreements, and liability agreements.

In the event of a default by the lessee, the problem must be resolved peacefully first. Amicable settlement carried out by PT. Adira Finance against the lesse if it is in default is to negotiate with the lessee regarding the payment of the rent. PT. Adira Finance can give the lessee additional time to pay off the outstanding rent. However, if the amicable settlement that has been carried out is not successful, then it is possible for the lessor to resolve the problem through legal means (courts).

\section{References}

Anwari, Ahmad. 1986. Leasing in Indonesia. Jakarta: Ghalia Indonesia. Ashfa, Burhan. 1996. Legal Research Methods. Jakarta : Rineka Cipta.

Badrulzaman, Mariam Darus. 2001. Compilation of the Law of Engagement. Bandung : Citra Aditya Bakti.

Fuady. 1995. Law on Financing in Theory and Practice. Bandung : Citra Aditya Bakti.

Please, M. Yahya. 1986. Legal aspects of treaties. Bandung : Alumni. Hadisaputra, Hartono. 1984. Civil Law Series. Yogyakarta : Liberty.

Hasbullah, Frieda Husni. 2002. Civil Material Law. Jakarta : Ind-Hill Co.

Kamello, Tan. 2006. Law Guarantee Fiduciary Something Needs Which coveted. Bandung : Alumni.

Meliala. 2007. Development of Civil Law Regarding Objects and Engagements. Bandung: Aulia nuance.

Muljadi Kartini, et al. 2004. Engagement in General. Jakarta : PT. King Grafindo Persada.

Margono, Suyud. 2000. Alternative Dispute Resolution (ADR) And Arbitration Institutional Process And Legal Aspects. Jakarta: Ghalia Indonesia.

Poerdaminta, WJS 1995. General Indonesian Dictionary. Jakarta: Balai Pustaka. 
Rachmad, Budi. 2004. Multi Finance Handbook. Jakarta: Pradnya Paramita. Syahrani, Ridwan. 1992. Ins and outs and Principles of Civil Law. Bandung :Alumni.

Salim, HS 2004. Development of Innominate Contract Law in Indonesia.

Jakarta : Sinar Graphic.

2004. Development of Guarantee Law in Indonesia. Jakarta : PT. King Grafindo Persada.

Sunaryo. 2008. Law on Financial Institutions. Jakarta : Sinar Graphic.

Subect. 1986. Law of Covenants. Jakarta : Rineka Cipta.

2001. Basics of Civil Law. Bandung : Alumni.

Satrio, J. 2002. Guarantee law, Property security rights. Bandung : Aditya Bakti.

Sofwan, Sri Soedewi Masjchun. 1980. Law of guarantees in Indonesia, Principles of Law on guarantees and individual guarantees. Yogyakarta : Liberty.

1982. Set Work About Law Guarantee. Yogyakarta : Liberty.

Soekadi, Eddy P. 1990. Leasing Mechanisms. Jakarta: Ghalia Indonesia.

Tunggal, Amin Widjaja, et al. 1994. Juridical Aspects in Leasing. Jakarta : PT. Rineka Cipta.

Show up, Ansari Siregar. 2005. Thesis Writing Methodology. Medan : Pustaka Bangsa Press.

Usman, Rachmadi. 2008. Civil Guarantee Law. Jakarta : Sinar Graphic.

2001. Alternative Business Law Dispute Resolution Series. Jakarta : PT. King Grafindo Persada.

Widjaja, Gunawan, et al. 2003. Fiduciary Guarantee. Jakarta : PT : Raja Grafindo Persada. 